\title{
Synergistic interaction between metformin and sulfonylureas on diclofenac-induced antinociception measured using the formalin test in rats
}

\author{
Mario I Ortiz $\mathrm{PhD}^{1,2}$
}

MI Ortiz. Synergistic interaction between metformin and sulfonylureas on diclofenac-induced antinociception measured using the formalin test in rats. Pain Res Manag 2013;18(5):253-258.

BACKGROUND: There is evidence that biguanides and sulfonylureas block diclofenac-induced antinociception (DIA) in rat models. However, little is known about the interaction between these hypoglycemics with respect to DIA.

OBJECTIVE: To determine whether metformin-sulfonylurea combinations affect DIA during the formalin test.

METHODS: Rats received the appropriate vehicle or diclofenac before $1 \%$ formaldehyde was injected into the paw. Rats were also pretreated with vehicle, glibenclamide, glipizide, metformin or glibenclamide/metformin and glipizide/metformin combinations before the diclofenac and formaldehyde injections, and the effect on antinociception was assessed. Isobolograms of the combinations were constructed to test for a synergistic interaction.

RESULTS: Systemic injection of diclofenac resulted in antinociception during the second phase of the test. Systemic pretreatment with the combinations of glibenclamide $(0.56 \mathrm{mg} / \mathrm{kg}$ to $10 \mathrm{mg} / \mathrm{kg}) / \mathrm{metformin}(10 \mathrm{mg} / \mathrm{kg}$ to $180 \mathrm{mg} / \mathrm{kg})$ and glipizide $(0.56 \mathrm{mg} / \mathrm{kg}$ to $10 \mathrm{mg} / \mathrm{kg}) / \mathrm{metformin}(10 \mathrm{mg} / \mathrm{kg}$ to $180 \mathrm{mg} / \mathrm{kg}$ ) blocked DIA. The derived theoretical effective doses for $50 \%$ of subjects $\left(\mathrm{ED}_{50}\right)$ for the glibenclamide/metformin and glipizide/ metformin combinations were $32.52 \mathrm{mg} / \mathrm{kg}$ and $32.42 \mathrm{mg} / \mathrm{kg}$, respectively, and were significantly higher than the actual observed experimental $\mathrm{ED}_{50}$ values $(7.57 \mathrm{mg} / \mathrm{kg}$ and $8.43 \mathrm{mg} / \mathrm{kg}$, respectively).

CONCLUSION: Pretreatment with glibenclamide, glipizide or metformin blocked DIA in a dose-dependent manner, and combining either sulfonylurea with metformin produced even greater effects. The observed $\mathrm{ED}_{50} \mathrm{~s}$ for the combinations were approximately fourfold lower than the calculated additive effects. These data indicate that sulfonylureas interact to produce antagonism of DIA. Combination therapy is a common secondline treatment for patients with diabetes and metabolic syndrome, a group that experiences pain from multiple sources. The results suggest that at least some anti-inflammatory agents may not be effective in this group.

Key Words: Diclofenac; Formalin test; Glibenclamide; Glipizide; $\mathrm{K}^{+}$channels; Metformin; Synergism

\footnotetext{
$\mathrm{t}$ is well known that insulin resistance is associated with obesity, par1 ticularly in patients with metabolic syndrome or type 2 diabetes mellitus (1). When left unmanaged, these diseases can result in hyperglycemia, which, over time, may lead to serious damage in many organ systems, particularly the nervous and cardiovascular systems $(1,2)$. In recent years, the approach to achieving and maintaining glycemic control in patients with metabolic syndrome and type 2 diabetes has been the use of combination therapy (metformin and a sulfonylurea) to simultaneously stimulate insulin secretion and reduce insulin resistance $(3,4)$. The sulfonylureas glibenclamide and glipizide improve glucose tolerance, predominantly by augmenting insulin secretion (5). At the cellular level, glibenclamide and glipizide act to inhibit ATPsensitive $\mathrm{K}^{+}$channels (6). In contrast, metformin is primarily an insulin-sensitizing agent that exhibits potent antihyperglycemic
}

\author{
L'interaction synergique entre la metformine et les \\ sulfonylurées sur l'antinociception induite par le \\ diclofénac mesurée au moyen du test au formol \\ chez des rats
}

HISTORIQUE : Selon certaines données, les biguanides et les sulfonylu-
rées bloquent l'antinociception induite par le diclofénac (AID) chez des
modèles de rats. Cependant, on ne sait pas grand-chose de l'interaction
entre ces hypoglycémiques et l'AID.
OBJECTIF : Déterminer si des associations de metformine et de sulfony-
lurée influent sur l'AID pendant le test au formol.
MÉTHODOLOGIE : Les chercheurs ont administré aux rats le véhicule
pertinent ou le diclofénac avant de leur injecter du formol $1 \%$ dans la patte.
Ils ont également prétraité les rats avec le véhicule, la glibenclamide, le
glipizide, la metformine ou l'association de glibenclamide et de metformine
ou de glipizide et de metformine avant les injections de diclofénac et de for-
mol, puis ont évalué l'effet de l'antinociception. Ils ont construit des isobolo-
grammes de ces associations pour en vérifier l'interaction synergique. RÉSULTATS : L'injection systémique de diclofénac suscitait une antinociception pendant la deuxième phase du test. Un prétraitement systémique avec l'association de glibenclamide $(0,56 \mathrm{mg} / \mathrm{kg}$ à $10 \mathrm{mg} / \mathrm{kg})$ et de metformine $(10 \mathrm{mg} / \mathrm{kg}$ à $180 \mathrm{mg} / \mathrm{kg})$ ou de glipizide $(0,56 \mathrm{mg} / \mathrm{kg}$ à $10 \mathrm{mg} / \mathrm{kg}$ ) et de metformine $(10 \mathrm{mg} / \mathrm{kg}$ à $180 \mathrm{mg} / \mathrm{kg}$ ) bloquait l'AID. Les doses efficaces théoriques pour $50 \%$ des sujets $\left(\mathrm{DE}_{50}\right)$ prenant une association de glibenclamide et de metformine ou de glipizide et de metformine correspondaient à $32,52 \mathrm{mg} / \mathrm{kg}$ et à $32,42 \mathrm{mg} / \mathrm{kg}$, respectivement, et étaient considérablement plus élevées que les valeurs des $\mathrm{DE}_{50}$ expérimentales observées (7,57 mg/kg et $8,43 \mathrm{mg} / \mathrm{kg}$, respectivement).

CONCLUSION : Un prétraitement à la glibenclamide, au glipizide ou à la metformine bloquait l'AID en fonction de la dose, et l'association de l'une des sulfonylurées à la metformine produisait encore plus d'effets. Les $\mathrm{DE}_{50}$ observées pour les associations étaient environ quatre fois plus faibles que les effets additionnels calculés. Selon ces données, les sulfonylurées interagissent pour produire un antagonisme de l'AID. La thérapie d'association est un traitement de deuxième ligne courant pour les parents atteints du diabète et du syndrome métabolique, un groupe ressentant des douleurs provenant de multiples sources. D'après les résultats, au moins certains anti-inflammatoires ne seraient pas efficaces au sein de ce groupe.

properties. Metformin suppresses hepatic gluconeogenesis and increases peripheral tissue insulin sensitivity $(7,8)$. Clinical studies have demonstrated that metformin-sulfonylurea combinations produce greater improvements in glycemic control than either sulfonylurea or metformin monotherapies (9-12). However, there are no animal studies that demonstrate a synergic hypoglycemic effect between metformin and sulfonylureas.

Recently, it was demonstrated that systemically delivered glibenclamide and glipizide reversed the antinociceptive and antihyperalgesic effects that are produced by systemic administration of diclofenac, suggesting that ATP-sensitive $\mathrm{K}^{+}$channels participate in these effects (13-15). Similarly, it was discovered that systemic and local peripheral administration of metformin and phenformin blocked the antinociceptive effects of diclofenac during the formalin test $(15,16)$.

\footnotetext{
${ }^{1}$ Área Académica de Medicina del Instituto de Ciencias de la Salud, Universidad Autónoma del Estado de Hidalgo, Pachuca; ${ }^{2}$ Departamento de Postgrado de la Universidad del Fútbol y Ciencias del Deporte, San Agustín Tlaxiaca, Hidalgo, Mexico

Correspondence: Dr Mario I Ortiz, Laboratorio de Farmacología, Área Académica de Medicina del Instituto de Ciencias de la Salud, Universidad Autónoma del Estado de Hidalgo, Eliseo Ramírez Ulloa 400, Col. Doctores. Pachuca, Hidalgo 42090, Mexico.

Telephone 52-77-1717-2000 ext 2361,fax 52-77-1717-2000 ext 2361, e-mail mario_i_ortiz@hotmail.com
} 
These results suggest that the interactions between sulfonylureas or biguanides with diclofenac may result in reduced analgesic efficacy. As mentioned above, the American Diabetes Association recommends the metformin-sulfonylurea combination as a second-line option in the management of diabetes; therefore, some diabetic patients are currently receiving this combination to control their glycemia $(4,17)$. Moreover, it is probable that diabetic patients are receiving the metformin-sulfonylurea combination simultaneously with nonsteroidal anti-inflammatory drugs (NSAIDs) such as diclofenac $(18,19)$. Therefore, the main objective of the present study was to evaluate the synergistic interaction between the metformin-glibenclamide and metformin-glipizide combinations on the antinociception induced by diclofenac during the formalin test in rats.

\begin{abstract}
METHODS
Animals

Male Wistar rats (eight to 10 weeks of age; body weight $200 \mathrm{~g}$ to $240 \mathrm{~g}$ ) from the author's facilities were used in the present study. The animals were maintained on a $12 \mathrm{~h}$ light $/ 12 \mathrm{~h}$ dark cycle, with the light period beginning at 07:00. The rats were housed in a special room at constant temperature $\left(22 \pm 2^{\circ} \mathrm{C}\right)$ and humidity $(50 \%)$. Animals were allowed free access to food and drinking water before experiments. Efforts were made to minimize animal suffering and to reduce the number of animals used. Each rat was used in only one experiment; at the end of the experiments, the animals were euthanized in a $\mathrm{CO}_{2}$ chamber. All experiments followed the Guidelines for Ethical Standards for Investigation of Experimental Pain in Animals (20) and were approved by the Institutional Animal Care and Use Committee.
\end{abstract}

\section{Drugs}

Diclofenac, glibenclamide, glipizide, metformin and formaldehyde were purchased from Sigma Corporation (USA). Diclofenac and metformin were dissolved in saline. Glibenclamide and glipizide were dissolved in a $20 \%$ dimethylsulfoxide solution.

\section{Assessment of nociception and antinociceptive activity}

Nociception was evaluated using the formalin test. Before the experiments, rats were placed in open Plexiglas observation chambers for $20 \mathrm{~min}$ on two consecutive days to allow them to acclimatize to their surroundings. On the third day, rats were placed in the same chambers for $30 \mathrm{~min}$; they were then removed for formaldehyde administration. Fifty microlitres of diluted formaldehyde ( $1 \%$ in $0.9 \%$ saline) were injected subcutaneously into the dorsal surface of the right hind paw. The animals were then returned to the chambers and nocifensive behaviour was observed immediately after formaldehyde injection. Nocifensive behaviour was quantified as the number of flinches of the injected paw during a $1 \mathrm{~min}$ period every $5 \mathrm{~min}$ for $60 \mathrm{~min}$ after injection. Formaldehydeinduced flinching behaviour is biphasic. The initial acute phase $(0 \mathrm{~min}$ to $10 \mathrm{~min}$ ) is followed by a relatively short quiescent period, which is then followed by a prolonged tonic response (15 $\mathrm{min}$ to $60 \mathrm{~min}$ ).

\section{Study design}

Rats received the appropriate vehicle $(1 \mathrm{~mL})$ or diclofenac $(10 \mathrm{mg} / \mathrm{kg}$ to $30 \mathrm{mg} / \mathrm{kg}$ intraperitoneally) $45 \mathrm{~min}$ before formaldehyde was injected into the paw. Similarly, rats were also pretreated with vehicle, glibenclamide $(0.56 \mathrm{mg} / \mathrm{kg}$ to $10 \mathrm{mg} / \mathrm{kg}$ subcutaneously), glipizide ( $0.56 \mathrm{mg} / \mathrm{kg}$ to $10 \mathrm{mg} / \mathrm{kg}$ subcutaneously), metformin (10 $\mathrm{mg} / \mathrm{kg}$ to $180 \mathrm{mg} / \mathrm{kg}$ subcutaneously) or the glibenclamide-metformin and glipizide-metformin combinations (see below for dosing details) $70 \mathrm{~min}$ before the formaldehyde injection, and the effect on antinociception was assessed. Drugs were injected in a volume of $1 \mathrm{~mL}$. Doses and timing of hypoglycemic and analgesic systemic administration were selected based on previous reports (15) and on pilot experiments performed in the author's laboratory.

Motor coordination test and blood glucose determination

In this experiment, individual drugs as well as drug combinations were assessed in different rats than those used in the formalin test.
Independent groups, each containing six to eight rats, were examined for motor coordination and blood glucose levels before and after administration of diclofenac ( $30 \mathrm{mg} / \mathrm{kg}$ intraperitoneally), glibenclamide $(10 \mathrm{mg} / \mathrm{kg})$, glipizide $(10 \mathrm{mg} / \mathrm{kg})$, metformin $(180 \mathrm{mg} / \mathrm{kg})$, diclofenac + glibenclamide, diclofenac + glipizide, diclofenac + metformin, diclofenac + glibenclamide + metformin, diclofenac + glipizide + metformin, or vehicles $(1 \mathrm{~mL})$. Animals were placed on a cylinder ( $7 \mathrm{~cm}$ in diameter) rotating at a speed of $20 \mathrm{rpm}$ (21). Rats were trained to walk on the cylinder in three consecutive sessions; on the fourth session, they received drug or vehicle treatment at time 0 , and the amount of time spent walking during a 2 min period was recorded at $1 \mathrm{~h}, 2 \mathrm{~h}$ and $3 \mathrm{~h}$ after treatment (21). Similarly, blood glucose levels were measured from the tail vein using the MediSense Optium glucose meter (Abbott, United Kingdom) before and at $1 \mathrm{~h}$, $2 \mathrm{~h}$ and $3 \mathrm{~h}$ after drug administration (21).

\section{Data analysis}

Results are presented as mean \pm SEM for six to eight animals per group. Time courses of antinociceptive response of diclofenac and the combinations were constructed by plotting the mean number of flinches as a function of time. The area under the curves (AUCs) for the number of flinches versus time were calculated by the trapezoidal rule. AUC was calculated for the second phase of the assay and per cent of antinociception was calculated according to the following equation (21):

$$
\begin{gathered}
\% \text { of antinociception }= \\
\left(\left[A \cup C_{\text {vehicle }}-\mathrm{AUC}_{\text {postcompound }}\right] / \mathrm{AUC}_{\text {vehicle }}\right) \times 100
\end{gathered}
$$

Dose-response curves were constructed using least squares linear regression, and the effective doses for $50 \%$ of subjects $\left(\mathrm{ED}_{50}\right) \pm \mathrm{SE}$ were calculated according to Tallarida (22). The interactions between metformin and sulfonylureas were characterized by isobolographic analysis assuming that the combinations are constituted by equi-effective doses of the individual drugs. Thus, from the dose-response curves of each individual agent, the $\mathrm{ED}_{50} \mathrm{~s}$ were determined. Considering a maximal effect of $100 \%$ to be the total suppression of the diclofenac-induced antinociception, in the present study the administration of glibenclamide, glipizide and metformin produced maximal effects of $93.8 \%, 91.9 \%$ and $86.1 \%$, respectively. Subsequently, a dose-response curve was obtained by concurrent delivery of two drugs (metformin plus a sulfonylurea) in a fixed ratio (1:1), based on the $\mathrm{ED}_{50}$ values of each individual agent. To construct these curves, groups of animals received diclofenac $(30 \mathrm{mg} / \mathrm{kg})$ and one of the following doses of the combination: metformin $\mathrm{ED}_{50} / 2+$ sulfonylurea $\mathrm{ED}_{50} / 2 ;$ metformin $\mathrm{ED}_{50} / 4+$ sulfonylurea $\mathrm{ED}_{50} / 4 ;$ metformin $\mathrm{ED}_{50} / 8+$ sulfonylurea $\mathrm{ED}_{50} / 8$; and metformin $\mathrm{ED}_{50} / 16$ + sulfonylurea $\mathrm{ED}_{50} / 16$. The experimental $\mathrm{ED}_{50}$ values for the combinations were calculated from these curves. The theoretical additive $\mathrm{ED}_{50} \mathrm{~s}$ were estimated from the dose-response curves of each drug administered individually, ie, assuming that the observed effect with the combination is the outcome of the sum of the effects of each the individual drug. These theoretical $\mathrm{ED}_{50}$ values were then compared with the experimentally derived $\mathrm{ED}_{50}$ values to determine whether there is a statistically significant difference $(23,24)$. The theoretical and experimental $\mathrm{ED}_{50}$ values of the studied combinations were also contrasted by calculating the interaction index $(\gamma)$ as follows: $\gamma=\mathrm{ED}_{50}$ of combination (experimental)/ED 50 of combination (theoretical).

An interaction index not significantly different from unity corresponds to an additive interaction, whereas values higher and lower than unity imply an antagonistic and synergistic interaction, respectively $(23,25)$.

\section{Statistical analysis}

Dose-response data were analyzed using ANOVA with Dunnett's test for post hoc comparison. Statistical significance between the theoretical additive $\mathrm{ED}_{50}$ and the experimentally derived $\mathrm{ED}_{50}$ values was evaluated using Student's $t$ test (22). An experimental $\mathrm{ED}_{50}$ 


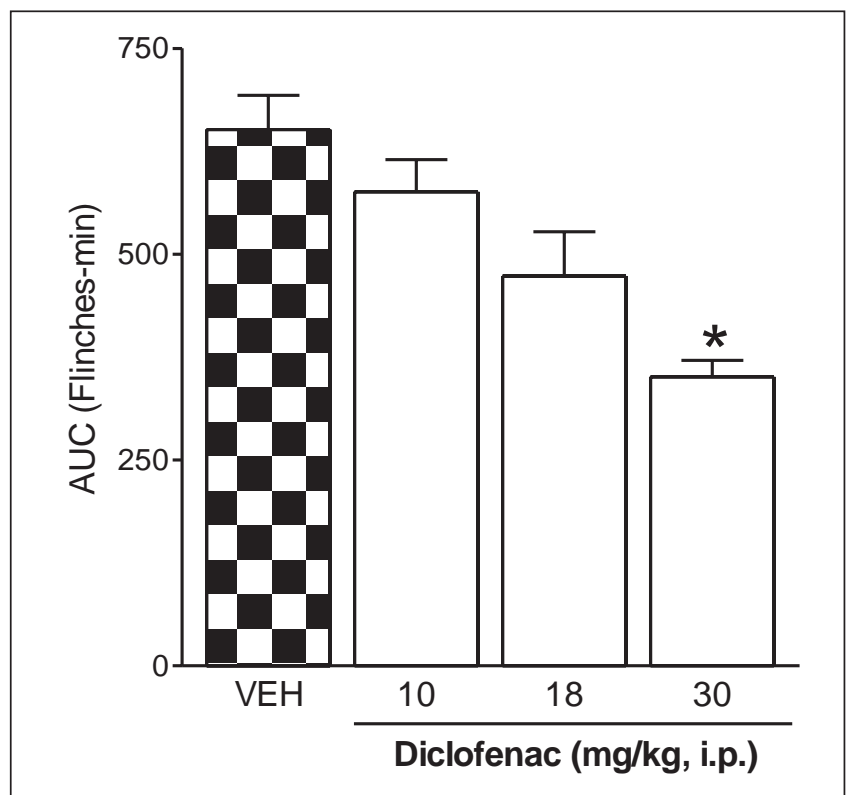

Figure 1) Systemic antinociceptive effect of diclofenac on results of the formalin test in rats. Rats were pretreated with systemic administration of vehicle (VEH) or diclofenac before formaldehyde injection. Data are expressed as the area under the number of flinches against time curve (AUC) on the second phase. Each bar represents the mean \pm SEM of six to eight animals. *Significantly different from the vehicle group $(P<0.05)$, determined using ANOVA followed by Dunnett's test. i.p. Intraperitoneal administration

significantly lower than the theoretical additive $\mathrm{ED}_{50}$ was considered to indicate a synergistic interaction between metformin and sulfonylureas. $\mathrm{P}<0.05$ was considered to be statistically significant.

\section{RESULTS}

Systemic antinociceptive effects of diclofenac in rats

Formaldehyde administration resulted in a typical pattern of flinching behaviour. The first phase of flinching began immediately after formaldehyde administration and diminished gradually over approximately 10 min (phase one), with a mean $( \pm$ SEM) of $125.4 \pm 10.9$ flinches. The second phase began approximately 15 min after administration and lasted until $1 \mathrm{~h}$ postadministration (phase two) with a mean of $651.25 \pm 41.7$ flinches. Systemic administration of diclofenac led to a reduction in flinching behaviour after formaldehyde injection in the rats (Figure 1). Diclofenac significantly reduced the number of flinches during phase two $(\mathrm{P}<0.05)$ (Figure 1) but not during phase one $(\mathrm{P}>0.05)$ (data not shown).

Effect of metformin and sulfonylureas on diclofenac-induced antinociception

Systemic pretreatment with metformin and two ATP-sensitive $\mathrm{K}^{+}$ channel inhibitors, glibenclamide or glipizide, blocked diclofenacinduced antinociception $(\mathrm{P}<0.05)$ (Figure 2A). Administered alone, metformin and sulfonylureas did not affect formaldehyde-induced nociceptive behaviour $(\mathrm{P}>0.05)$ (data not shown). $\mathrm{ED}_{50}$ values for systemic metformin, glibenclamide and glipizide on the diclofenacinduced antinociception measured during the formalin test were $62.56 \pm 21.3 \mathrm{mg} / \mathrm{kg}, 2.49 \pm 0.12 \mathrm{mg} / \mathrm{kg}$ and $2.28 \pm 0.29 \mathrm{mg} / \mathrm{kg}$, respectively. The theoretical additive $\mathrm{ED}_{50} \mathrm{~s}$ were estimated from these doseresponse curves of each drug administered individually as follows: the theoretical additive $\mathrm{ED}_{50}$ was determined to be $32.52 \mathrm{mg} / \mathrm{kg}$ for the glibenclamide-metformin combination and $32.42 \mathrm{mg} / \mathrm{kg}$ for the glipizide-metformin combination.

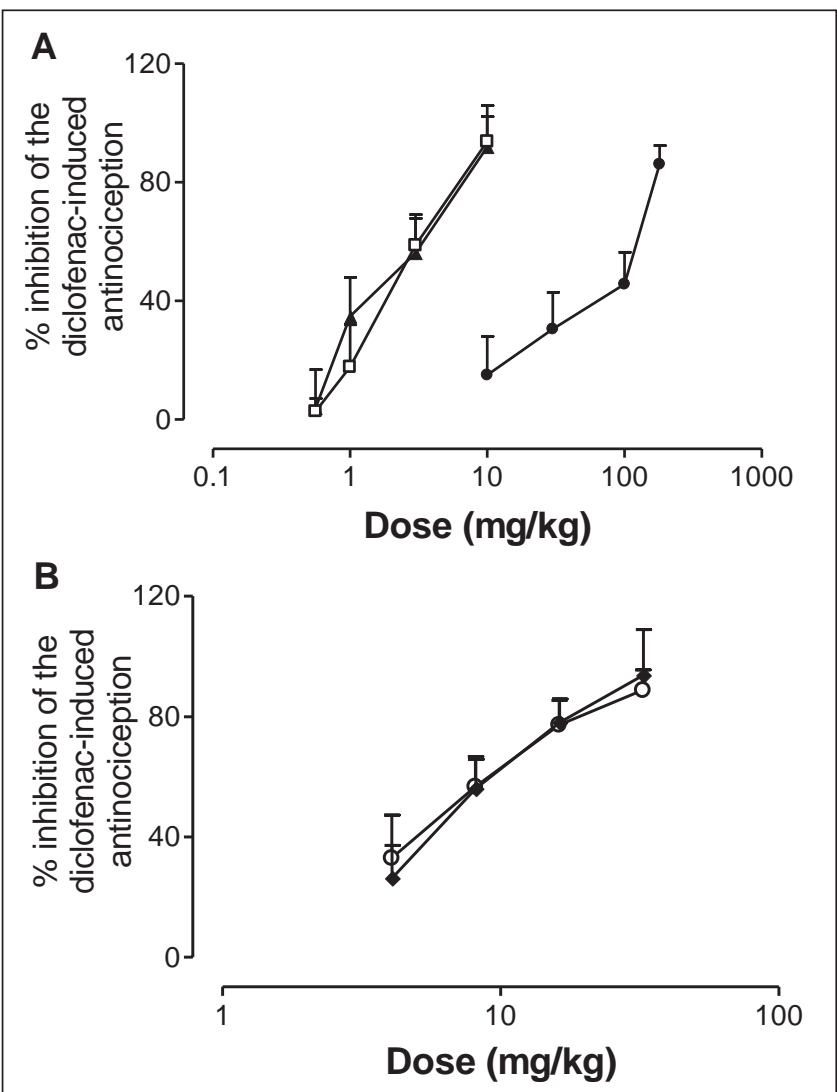

Figure 2) Systemic effect of hypoglycemic drugs on the systemic antinociceptive activity of diclofenac $(30 \mathrm{mg} / \mathrm{kg})$ during the formalin test in rats. Each point corresponds to the mean \pm SEM of six to eight animals. A Rats were pretreated with systemic glibenclamide $(\square)$, glipizide $(\boldsymbol{\Delta})$ or metformin (•) before diclofenac and formaldehyde injection. Doses of glibenclamide and glipizide were $0.56 \mathrm{mg} / \mathrm{kg}, 1 \mathrm{mg} / \mathrm{kg}, 3 \mathrm{mg} / \mathrm{kg}$ and $10 \mathrm{mg} / \mathrm{kg}$. Doses of metformin were $10 \mathrm{mg} / \mathrm{kg}, 30 \mathrm{mg} / \mathrm{kg}, 100 \mathrm{mg} / \mathrm{kg}$ and $180 \mathrm{mg} / \mathrm{kg}$. B Animals were pretreated with systemic glibenclamide + metformin $(\$)$ or glipizide + metformin ( $\mathrm{O}$ ) before diclofenac and formaldehyde injection. Total doses of the glibenclamide-metformin combination were $4.07 \mathrm{mg} / \mathrm{kg}, 8.14 \mathrm{mg} / \mathrm{kg}$, $16.28 \mathrm{mg} / \mathrm{kg}$ and $32.55 \mathrm{mg} / \mathrm{kg}$. Total doses of the glipizide-metformin combination were $4.06 \mathrm{mg} / \mathrm{kg}, 8.11 \mathrm{mg} / \mathrm{kg}, 16.23 \mathrm{mg} / \mathrm{kg}$ and $32.45 \mathrm{mg} / \mathrm{kg}$

Interactive effect of metformin and sulfonylureas on diclofenacinduced antinociception

Fixed-dose ratio combinations (1:1) were prepared as described in the Methods section, and were assayed to construct the dose-response curves for the metformin-glibenclamide and metformin-glipizide combinations. The corresponding experimental $\mathrm{ED}_{50} \mathrm{~s}$ were calculated to be $7.57 \pm 0.7 \mathrm{mg} / \mathrm{kg}$ and $8.43 \pm 1.6 \mathrm{mg} / \mathrm{kg}$, respectively (Figure 2B). These values were significantly lower $(\mathrm{P}<0.05)$ than the theoretical $\mathrm{ED}_{50} \mathrm{~s}$ expected for a purely additive interaction, which were $32.52 \pm 10.64 \mathrm{mg} / \mathrm{kg}$ and $32.42 \pm 10.65 \mathrm{mg} / \mathrm{kg}$, as shown in Figure 3, in which the experimental $\mathrm{ED}_{50} \mathrm{~s}$ are located below the additive dose line. Furthermore, the interaction indexes $(\gamma)$ for the metformin-glibenclamide and metformin-glipizide combinations were $0.23 \pm 0.1$ and $0.26 \pm 0.1$, respectively, being statistically different from unity. These results strongly suggest that the interaction between the actions of metformin and sulfonylureas at the systemic level are synergistic, the resulting effect being approximately four times higher than that expected by the sum of the effects of the individual components.

Effect of metformin, sulfonylureas and diclofenac on motor coordination and blood glucose levels

Systemic treatment with diclofenac, glibenclamide, glipizide, metformin or combinations of these drugs did not alter motor coordination 


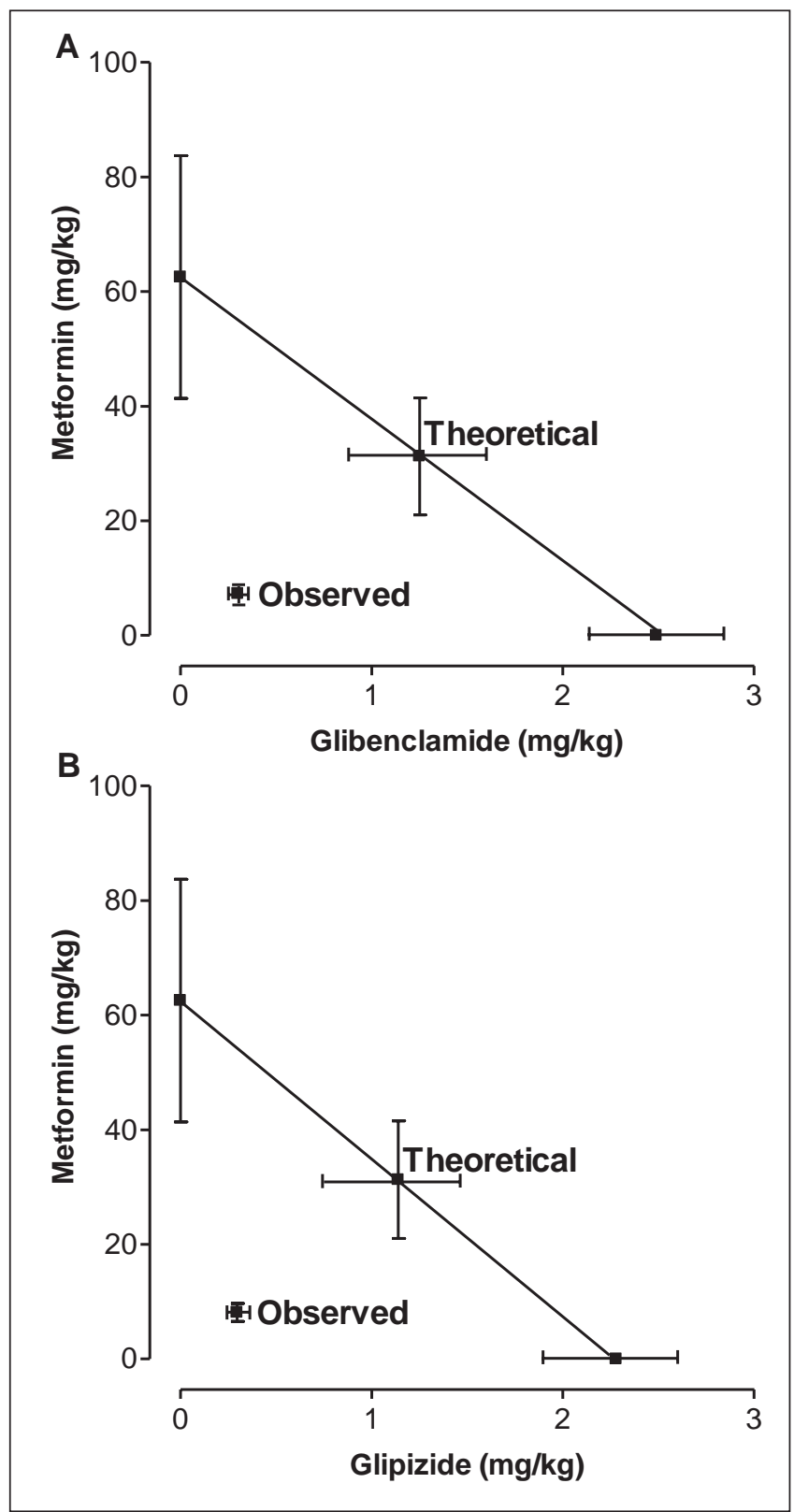

Figure 3) Isobolograms showing the systemic interaction between metformin and sulfonylureas (fixed-dose ratio 1:1) on diclofenac antinociception. A Metformin-glibenclamide combination; B Metformin-glipizide combination. The oblique lines between the $x$ and $y$ axis are the theoretical additive lines. The points in the middle of these lines are the theoretical additive points calculated from the individual effective doses for $50 \%$ of subjects $\left(E D_{50}\right)$. The observed points (experimental) are the actually observed $E D_{50}$ values with the combinations. Horizontal and vertical bars indicate SEM. Thus, when combined, the doses of metformin and sulfonylureas that produce a 50\% reduction in the antinociceptive effect of diclofenac are four-to fivefold lower than would be expected if the effects were additive

in the rats $(\mathrm{P}>0.05$; Table 1$)$. Systemic administration of diclofenac and metformin did not significantly reduce blood glucose levels in rats $(P>0.05$; Table 2$)$. However, systemic administration of glibenclamide, glipizide or combinations of these drugs with diclofenac significantly altered blood glucose levels in the rats $(\mathrm{P}<0.05$; Table 2$)$. Similarly, the diclofenac-metformin-sulfonylurea combinations significantly reduced the blood glucose levels in rats $(\mathrm{P}<0.05$; Table 2$)$.
TABLE 1

Effect of diclofenac, metformin and sulfonylureas and their combinations on motor coordination

\begin{tabular}{lccc}
\hline & \multicolumn{3}{c}{ Time after drug administration } \\
\cline { 2 - 4 } Treatment & $\mathbf{1 ~ \mathbf { ~ }}$ & $\mathbf{2 ~ \mathbf { ~ }}$ & $\mathbf{3 ~ \mathbf { ~ }}$ \\
\hline Control & $115.0 \pm 1.9$ & $116.2 \pm 2.1$ & $114.4 \pm 1.5$ \\
Diclofenac $30 \mathrm{mg} / \mathrm{kg}$ & $116.0 \pm 1.9$ & $114.5 \pm 2.6$ & $114.1 \pm 1.8$ \\
Glibenclamide $10 \mathrm{mg} / \mathrm{kg}$ & $118.3 \pm 1.3$ & $116.7 \pm 2.8$ & $115.0 \pm 0.8$ \\
Glipizide $10 \mathrm{mg} / \mathrm{kg}$ & $113.9 \pm 2.9$ & $115.0 \pm 2.6$ & $111.1 \pm 3.7$ \\
Metformin $180 \mathrm{mg} / \mathrm{kg}$ & $113.8 \pm 6.3$ & $110.0 \pm 8.4$ & $113.8 \pm 6.3$ \\
Diclofenac + glibenclamide & $116.0 \pm 2.7$ & $113.0 \pm 2.7$ & $110.0 \pm 2.9$ \\
Diclofenac + glipizide & $117.9 \pm 1.9$ & $116.9 \pm 1.9$ & $112.5 \pm 2.1$ \\
Diclofenac + metformin & $120.0 \pm 0.0$ & $118.8 \pm 1.3$ & $112.5 \pm 7.5$ \\
Diclofenac + glibenclamide + metformin & $115.9 \pm 2.9$ & $116.3 \pm 3.8$ & $118.8 \pm 1.3$ \\
Diclofenac + glipizide + metformin & $113.6 \pm 2.6$ & $116.8 \pm 2.2$ & $114.0 \pm 4.8$ \\
\hline
\end{tabular}

Data correspond to the mean \pm SEM time walked, in s, by six to eight animals. Rats were pretreated with vehicle or the indicated drugs before the rotarod test. All the animals walked during a $120 \mathrm{~s}$ period at the basal time (0 min).

TABLE 2

Effect of diclofenac, metformin and sulfonylureas and combinations thereof on blood glucose levels

\begin{tabular}{llll}
\hline & \multicolumn{3}{c}{ Time after drug administration } \\
\cline { 2 - 4 } Treatment & \multicolumn{1}{c}{$\mathbf{1} \mathbf{~}$} & \multicolumn{1}{c}{$\mathbf{2} \mathbf{~}$} & $\mathbf{3} \mathbf{~ h}$ \\
\hline Control & $88.3 \pm 3.9$ & $88.0 \pm 6.3$ & $89.3 \pm 2.3$ \\
Diclofenac $30 \mathrm{mg} / \mathrm{kg}$ & $92.7 \pm 6.2$ & $81.3 \pm 3.5$ & $85.7 \pm 4.7$ \\
Glibenclamide $10 \mathrm{mg} / \mathrm{kg}$ & $43.3 \pm 7.2^{*}$ & $39.7 \pm 4.5^{*}$ & $39.0 \pm 4.8^{*}$ \\
Glipizide $10 \mathrm{mg} / \mathrm{kg}$ & $42.3 \pm 3.6^{*}$ & $38.3 \pm 7.0^{*}$ & $40.8 \pm 7.7^{*}$ \\
Metformin $180 \mathrm{mg} / \mathrm{kg}$ & $73.8 \pm 6.4$ & $69.3 \pm 7.4$ & $70.5 \pm 3.3$ \\
Diclofenac + glibenclamide & $45.5 \pm 4.5^{*}$ & $45.0 \pm 7.0^{*}$ & $47.0 \pm 6.0^{*}$ \\
Diclofenac + glipizide & $50.3 \pm 5.5^{*}$ & $46.3 \pm 4.3^{*}$ & $51.3 \pm 5.5^{*}$ \\
Diclofenac + metformin & $69.8 \pm 3.9$ & $77.8 \pm 3.1$ & $70.5 \pm 7.8$ \\
Diclofenac + glibenclamide + metformin & $33.5 \pm 4.8^{*}$ & $38.5 \pm 7.5^{*}$ & $35.0 \pm 5.6^{*}$ \\
Diclofenac + glipizide + metformin & $39.8 \pm 2.5^{*}$ & $40.8 \pm 3.9^{*}$ & $41.0 \pm 3.9^{*}$ \\
\hline
\end{tabular}

Data presented as mean \pm SEM of blood glucose levels $(\mathrm{mg} / \mathrm{dL})$ in six to eight animals per group. Rats were pretreated with vehicle or the indicated drugs before measurement of blood glucose levels. At the basal time (0 min), animals had normal blood glucose levels (mean [ \pm SEM] of $86.6 \pm 3.3 \mathrm{mg} / \mathrm{dL}$ ). *Significantly different from control group $(P<0.05)$, determined using ANOVA followed by Dunnett's test

\section{DISCUSSION}

In the formalin test, diluted formaldehyde is injected subcutaneously into a hind paw and nociceptive behaviour is scored. Two phases of the response are observed: an early phase starting immediately after injection and lasting $5 \mathrm{~min}$ to $10 \mathrm{~min}$; and a late phase $15 \mathrm{~min}$ to $60 \mathrm{~min}$ after injection (26). It is now known that the first phase is due to a direct effect of formalin on nociceptors, whereas the second phase is mediated by a combination of peripheral input and spinal cord sensitization (26-31). Opioid analgesics appear to be antinociceptive for both phases, although the second is more sensitive to these drugs. In contrast, systemic, supraspinal, spinal and local peripheral administrations of some NSAIDs appear to suppress only the second phase of the formaldehyde-induced nocifensive behaviour (26-31). In the present study, systemic administration of diclofenac was able to decrease the nociceptive effect induced by formaldehyde. These data are consistent with previous studies showing that systemic administration of diclofenac produced a significant antinociceptive effect in the same model and other models (13-15).

Sulfonylureas stimulate insulin secretion without an effect on insulin synthesis, and act through the blockade of ATP-sensitive $\mathrm{K}^{+}$channels in pancreatic cells $(6,32)$. This leads to depolarization of the plasma membrane, with opening of voltage-dependent calcium channels and 
inflow of calcium ions, leading to activation of insulin exocytosis in a similar manner to that found after stimulation with glucose (32). In the present work, systemic administration of glibenclamide or glipizide decreased diclofenac-induced antinociceptive effects in rats. This result is consistent with previous results showing that systemic, spinal or peripheral administration of glibenclamide is able to block the effects of diclofenac treatment (13-16,25,30,31). In addition, treatment with sulfonylureas alone and in combination with diclofenac significantly reduced blood glucose levels compared with treatment with diclofenac alone in the present study. However, treatment with sulfonylureas alone or in combination with diclofenac did not alter motor coordination in these rats. Therefore, blockade of diclofenac-induced antinociception by sulfonylureas does not appear to occur as a result of a hypoglycemic effect or of motor alteration. Furthermore, the data suggest that this blockage was a result of ATP-sensitive $\mathrm{K}^{+}$channel inhibition.

In the present study, systemic administration of metformin was able to reverse diclofenac-induced antinociception. This effect was not a result of changes in motor coordination or a decrease in blood glucose levels because administration of metformin in combination with diclofenac did not significantly alter these two variables. Therefore, it is possible that diclofenac activates metformin-dependent pathways at a systemic level (33-39). However, the precise mechanisms by which metformin reverses diclofenac-induced antinociception should be addressed in future experiments.

It is widely known the type 2 diabetes mellitus is a progressive disease and combination therapy is a logical approach to its management. It has been demonstrated that after three years, type 2 diabetes mellitus was adequately controlled with a single drug in only $50 \%$ of patients; after nine years, this percentage decreased to only $25 \%$ of patients (40). In general, the most popular combinations are: metformin plus sulfonylurea; metformin plus thiazolidinedione; and sulfonylurea plus thiazolidinedione. Combination therapy involving two drug classes with distinct mechanisms of action will not only improve glycemic control, but will also result in lower overall drug dosing in some settings and minimize adverse effects (17). However, the majority of studies investigating combinations of hypoglycemic drugs focus only on the effects on blood glucose (or hemoglobin A1c) and adverse reactions (9-12), and do not assess the probable pharmacokinetic or pharmacodynamic interactions with other nonantidiabetic drugs such as anxiolytics, NSAIDs, anticonvulsants, antihyperlipidemics and antithrombotics, among others $(18,19)$. The results of the present study showed that the metformin-sulfonylurea combinations were able to block diclofenac-induced antinociception during the formalin test. Therefore, if diclofenac, metformin and a sulfonylurea are administered simultaneously in patients with diabetes, it is possible that this triple combination may affect the effect of diclofenac. Diabetes mellitus affects structural macromolecules of the extracellular matrix in vessels and connective tissues in multiple ways and causes different alterations in periarticular, muscular and skeletal systems (41-48). Musculoskeletal disorders of the upper extremity, such as shoulder adhesive capsulitis, Dupuytren disease, carpal tunnel syndrome and stenosing flexor tenosynovitis (trigger finger), are widely associated with diabetes mellitus (45-48). NSAIDs and physical therapy remain the primary therapeutic modalities for some of these diabetic patients. Similarly, NSAIDs are used in preventing macular edema after phacoemulsification and the treatment of osteoarthritis or rheumatoid arthritis in diabetic patients $(41-48)$. Therefore, it is possible that diabetic patients with comorbidities (musculoskeletal disorders, postsurgical or pain and inflammation caused by disease or trauma) are receiving therapy with diclofenac, metformin and a sulfonylurea. Clinical studies to establish the relevance of these interactions are warranted.

In addition, treatment with the metformin-sulfonylurea-diclofenac mixtures significantly reduced blood glucose levels compared with treatment with diclofenac or metformin in the present study. However, treatment with the metformin-sulfonylurea-diclofenac combinations did not alter motor coordination in these rats. Therefore, blockade of diclofenac-induced antinociception by metformin-sulfonylurea combinations does not appear to be the result of a hypoglycemic effect or of motor alteration.

\section{SUMMARY}

The results of the present study show that systemic metforminsulfonylurea combinations are able to block diclofenac-induced antinociception in rats. The data suggest that low doses of the biguanide-sulfonylurea combination can interact synergistically at a systemic level and, therefore, this drug interaction may represent a therapeutic disadvantage in the clinical use of diclofenac. The true consequences of these interactions in clinical situations await supplementary validation.

\section{REFERENCES}

1. Campbell RK. Type 2 diabetes - where we are today: An overview of disease burden, current treatments, and treatment strategies. J Am Pharm Assoc 2009;49:S3-S9.

2. Guastella V, Mick G. Strategies for the diagnosis and treatment of neuropathic pain secondary to diabetic peripheral sensory polyneuropathy. Diab Metab 2009;35:12-9.

3. De Fronzo RA, Goodman AM. Efficacy of metformin in patients with non-insulin-dependent diabetes mellitus. The Multicenter Metformin Study Group. N Engl J Med 1995;333:541-9.

4. Nathan DM, Buse JB, Davidson MB, et al. American Diabetes Association; European Association for Study of Diabetes. Medical management of hyperglycemia in type 2 diabetes: A consensus algorithm for the initiation and adjustment of therapy: A consensus statement of the American Diabetes Association and the European Association for the Study of Diabetes. Diabetes Care 2009;32:193-203.

5. Luzi L, Pozza G. Glibenclamide: An old drug with a novel mechanism of action? Acta Diabetol 1997;34:239-44.

6. Edwards G, Weston AH. The pharmacology of ATP-sensitive $\mathrm{K}^{+}$ channels. Annu Rev Pharmacol Toxicol 1993;33:597-637.

7. Lochhead PA, Salt IP, Walker KS, Hardie DG, Sutherland C. 5-aminoimidazole-4-carboxamide riboside mimics the effects of insulin on the expression of the 2 key gluconeogenic genes PEPCK and glucose-6-phosphatase. Diabetes 2000;49:896-903.

8. Zhou G, Myers R, Li Y, et al. Role of AMP-activated protein kinase in mechanism of metformin action. J Clin Invest 2001;108:1167-74.

9. Garber AJ, Larsen J, Schneider SH, Piper BA, Henry D. Glyburide/ Metformin Initial Therapy Study Group. Simultaneous glyburide/ metformin therapy is superior to component monotherapy as an initial pharmacological treatment for type 2 diabetes. Diabetes Obes Metab 2002;4:201-8.

10. Garber AJ, Donovan DS Jr, Dandona P, Bruce S, Park JS. Efficacy of glyburide/metformin tablets compared with initial monotherapy in type 2 diabetes. J Clin Endocrinol Metab 2003;88:3598-604.

11. Duckworth W, Marcelli M, Padden M, et al. Improvements in glycemic control in type 2 diabetes patients switched from sulfonylurea coadministered with metformin to glyburide-metformin tablets. J Manag Care Pharm 2003;9:256-62.

12. Chien HH, Chang CT, Chu NF, et al. Effect of glyburide-metformin combination tablet in patients with type 2 diabetes. J Chin Med Assoc 2007;70:473-80.

13. Ortiz MI, Castañeda-Hernández G. Glibenclamide reduces the diclofenac-induced antihyperalgesia on the Hargreaves model of thermal hyperalgesia. Proc West Pharmacol Soc 2006;49:134-6.

14. León-Reyes MR, Castañeda-Hernández G, Ortiz MI. Pharmacokinetic of diclofenac in the presence and absence of glibenclamide in the rat. J Pharm Pharm Sci 2009;12:280-7.

15. Ortiz MI. Blockade of the antinociception induced by diclofenac, but not of indomethacin, by sulfonylureas and biguanides. Pharmacol Biochem Behav 2011;99:1-6.

16. Ortiz MI. Metformin and phenformin block the peripheral antinociception induced by diclofenac and indomethacin on the formalin test. Life Sci 2012;90:8-12.

17. Erle G, Lovise S, Stocchiero C, et al. A comparison of preconstituted, fixed combinations of lowdose glyburide plus metformin versus high-dose glyburide alone in the treatment of type 2 diabetic patients. Acta Diabetol 1999;36:61-5.

18. Yusuff KB, Balogun OB. Pattern of drug utilization among hypertensives in a Nigerian teaching hospital. Pharmacoepidemiol Drug Saf 2005;14:69-74. 
19. Scheen AJ. Drug interactions of clinical importance with antihyperglycaemic agents: An update. Drug Saf 2005;28:601-31.

20. Zimmermann M. Ethical guidelines for investigations of experimental pain in conscious animals. Pain 1983;16:109-10.

21. Ortiz MI, Ramírez-Montiel ML, González-García MP, Ponce-Monter HA, Castañeda-Hernández G, Cariño-Cortés R. The combination of naproxen and citral reduces nociception and gastric damage in rats. Arch Pharm Res 2010;33:1691-7.

22. Tallarida RJ. Drug Synergism and Dose-Effect Data Analysis, 1st edn. New York: Chapman \& Hall/CRC;2000:1-72.

23. Tallarida RJ. The interaction index: A measure of drug synergism. Pain 2002;98:163-8.

24. Tallarida RJ, Cowan A, Raffa RB. Antinociceptive synergy, additivity, and subadditivity with combinations of oral glucosamine plus nonopioid analgesics in mice. J Pharmacol Exp Ther 2003;307:699-704.

25. Ortiz MI, Lozano-Cuenca J, Granados-Soto V, Castañeda-Hernández G. Additive interaction between peripheral and central mechanisms involved in the antinociceptive effect of diclofenac in the formalin test in rats. Pharmacol Biochem Behav 2008;91:32-7.

26. Dubuisson D, Dennis SG. The formalin test: A quantitative study of the analgesic effects of morphine, meperidine, and brain stem stimulation in rats and cats. Pain 1997;4:161-74.

27. Malmberg AB, Yaksh TL. Antinociceptive actions of spinal nonsteroidal anti-inflammatory agents on the formalin test in the rat. J Pharmacol Exp Ther 1992;263:136-46.

28. Yaksh TL, Malmberg AB. Spinal actions of NSAIDS in blocking spinally mediated hyperalgesia: The role of cyclooxygenase products. Agents Actions Suppl 1993;41:89-100.

29. Björkman R. Central antinociceptive effects of non-steroidal antiinflammatory drugs and paracetamol. Experimental studies in the rat. Acta Anaesthesiol Scand 1995;103:1-44.

30. Ortiz MI, Torres-López JE, Castañeda-Hernández G, Rosas R, Vidal-Cantú GC, Granados-Soto V. Pharmacological evidence for the activation of $\mathrm{K}(+)$ channels by diclofenac. Eur J Pharmacol 2002;438:85-91.

31. Ortiz MI, Granados-Soto V, Castañeda-Hernández G. The NO-cGMP-K $(+)$ channel pathway participates in the antinociceptive effect of diclofenac, but not of indomethacin. Pharmacol Biochem Behav 2003;76:187-95.

32. Bataille D. Molecular mechanisms of insulin secretion. Diabetes Metab 2002;28:4S7-4S13.

33. Lee JM, Peuler JD. A possible indirect sympathomimetic action of metformin in the arterial vessel wall of spontaneously hypertensive rats. Life Sci 2001;69:1085-92.
34. Lutz TA, Estermann A, Haag S, Scharrer E. Depolarization of the liver cell membrane by metformin. Biochim Biophys Acta 2001;1513:176-84.

35. Bhalla RC, Toth KF, Tan E, Bhatty RA, Mathias E, Sharma RV. Vascular effects of metformin. Possible mechanisms for its antihypertensive action in the spontaneously hypertensive rat. Am J Hypertens 1996;9:570-6.

36. Peuler JD. Opposing adrenergic actions of intravenous metformin on arterial pressure in female spontaneously hypertensive rats. Cardiovasc Res 1999;43:237-47.

37. Cheng JT, Huang CC, Liu IM, Tzeng TF, Chang CJ. Novel mechanism for plasma glucose-lowering action of metformin in streptozotocin-induced diabetic rats. Diabetes 2006;55:819-25.

38. North RA. Twelfth Gaddum memorial lecture. Drug receptors and the inhibition of nerve cells. Br J Pharmacol 1989;98:13-28.

39. Tseng LF. Evidence for epsilon-opioid receptor-mediated betaendorphin-induced analgesia. Trends Pharmacol Sci 2002;22:623-30.

40. Turner RC, Cull CA, Frighi V, Holman RR; The UKPDS Group. Glycemic control with diet, sulfonylurea, metformin, or insulin in patients with type 2 diabetes mellitus. JAMA 1999;281:2005-12.

41. Li MC, Yang XR, Liu F, Shao DP, Li YB. Effect of topical NSAIDs in preventing macular edema after phacoemulsification in diabetes. Int J Ophthalmol 2011;11:1483-4.

42. Shakeel H, Ahmad TS. Steroid injection versus NSAID injection for trigger finger: A comparative study of early outcomes. J Hand Surg Am 2012;37:1319-23.

43. Rho YH, Oeser A, Chung CP, Milne GL, Stein CM. Drugs used in the treatment of rheumatoid arthritis: Relationship between current use and cardiovascular risk factors. Arch Drug Inf 2009;2:34-40.

44. Matchaba P, Gitton X, Krammer G, et al. Cardiovascular safety of lumiracoxib: A meta-analysis of all randomized controlled trials $>$ or $=1$ week and up to 1 year in duration of patients with osteoarthritis and rheumatoid arthritis. Clin Ther 2005;27:1196-214.

45. Fitzgibbons PG, Weiss AP. Hand manifestations of diabetes mellitus. J Hand Surg Am 2008;33:771-5.

46. Lebiedz-Odrobina D, Kay J. Rheumatic manifestations of diabetes mellitus. Rheum Dis Clin North Am 2010;36:681-99.

47. Rosenbloom AL, Silverstein JH. Connective tissue and joint disease in diabetes mellitus. Endocrinol Metab Clin North Am 1996;25:473-83.

48. Garcilazo C, Cavallasca JA, Musuruana JL. Shoulder manifestations of diabetes mellitus. Curr Diabetes Rev 2010;6:334-40. 


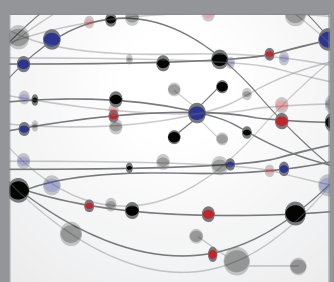

The Scientific World Journal
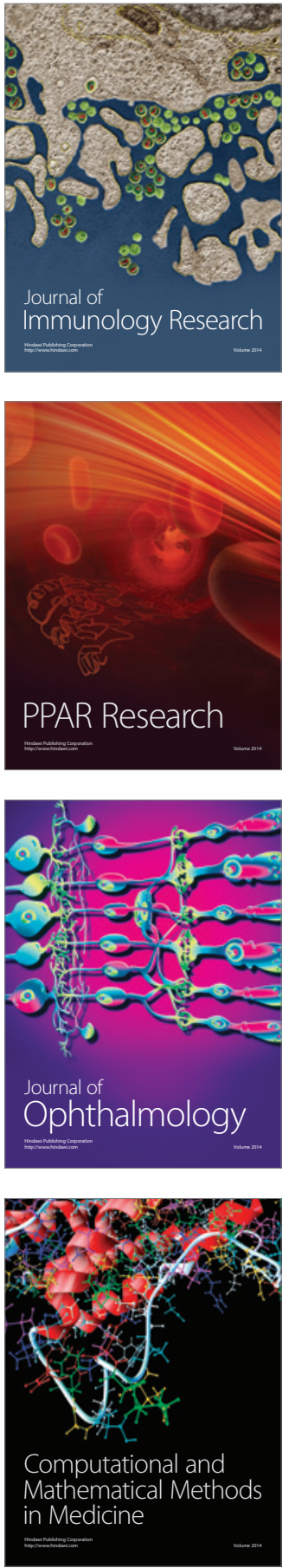

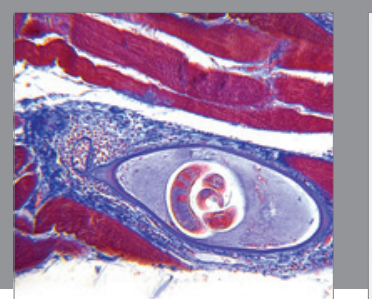

Gastroenterology Research and Practice

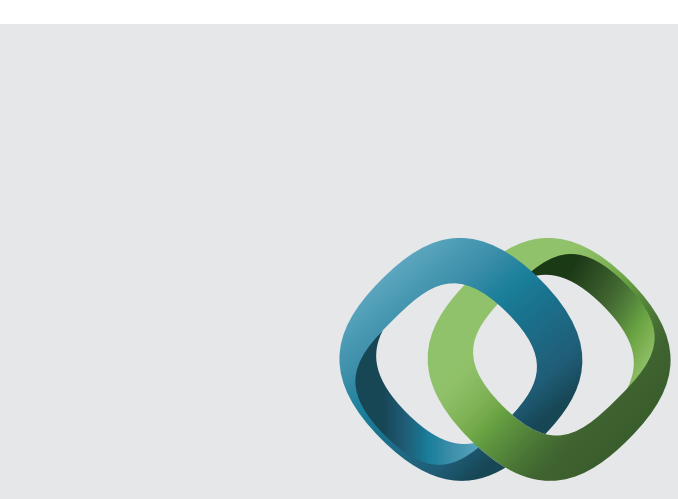

\section{Hindawi}

Submit your manuscripts at

http://www.hindawi.com
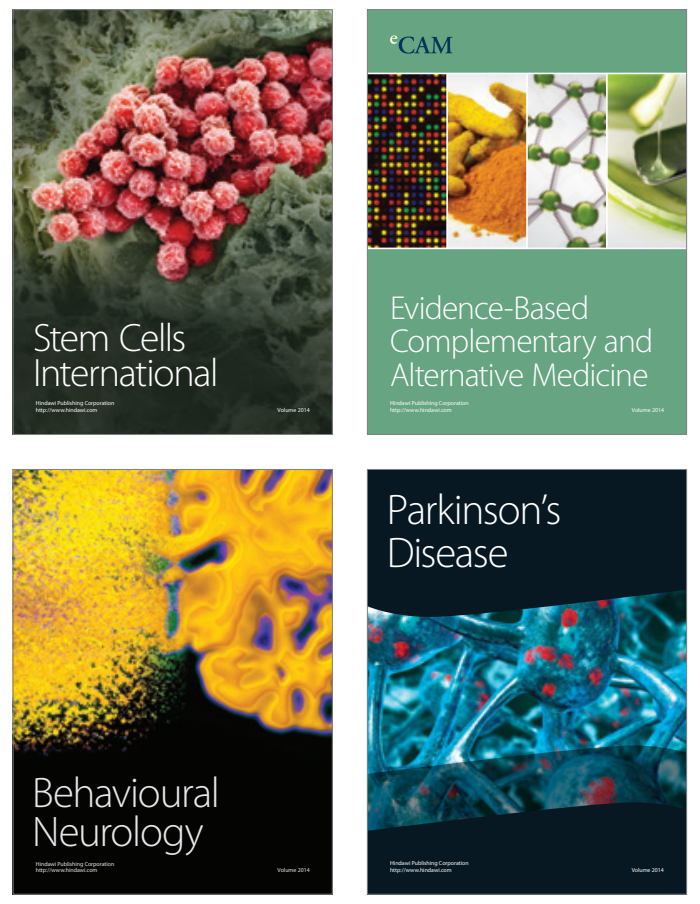
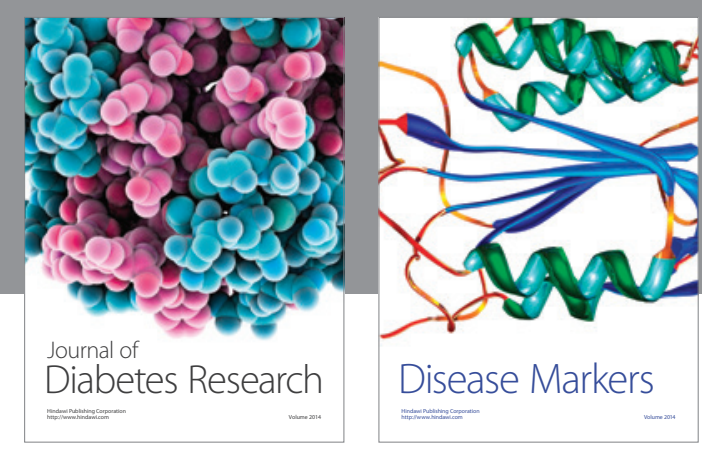

Disease Markers
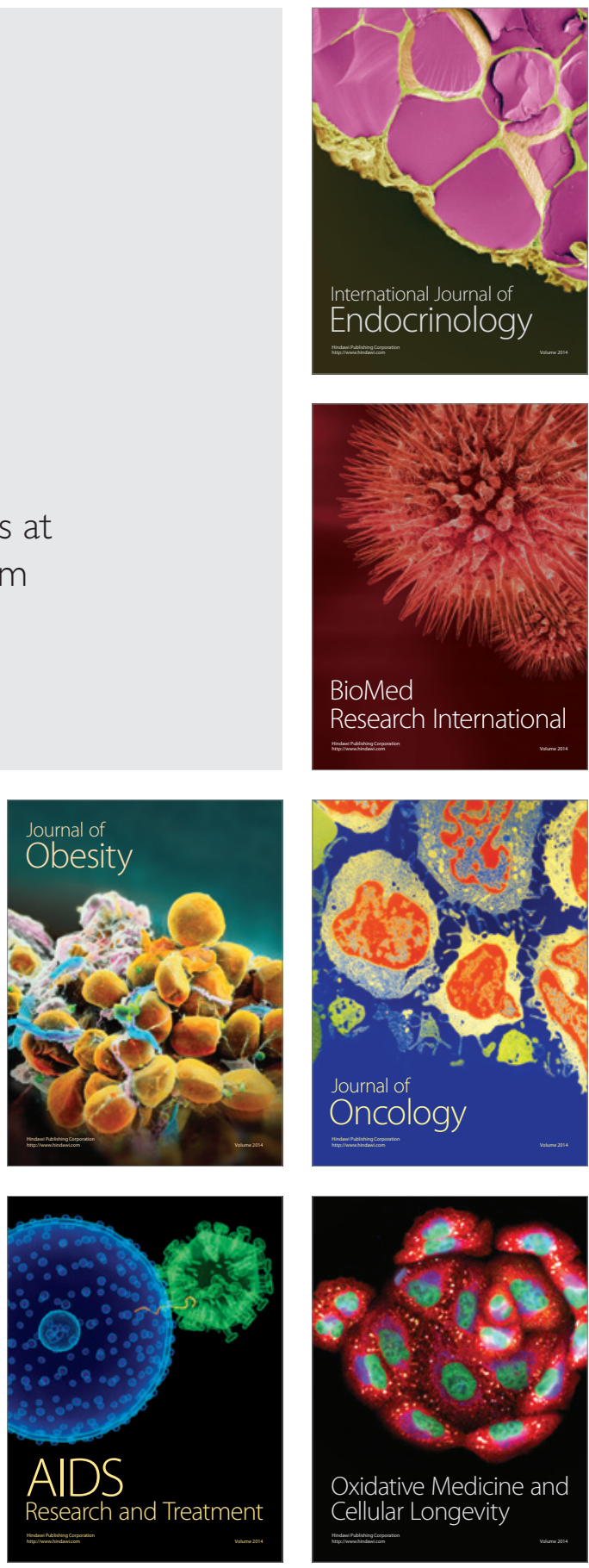